
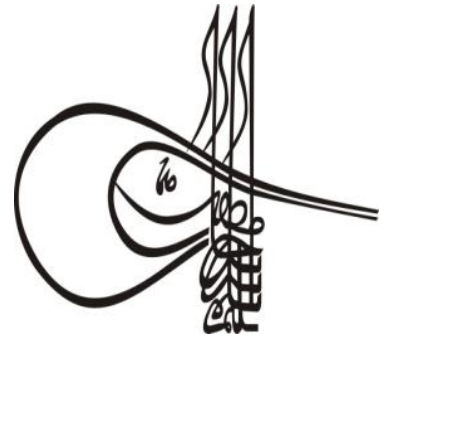

Received/Geliș: 29.08.2019

Gon Report Dates/Rapor Tarihleri: Referee 1 (11.09.2019)-Referee 2 (10.10.2019)

\section{Turkigh Studies Educational Sciences}

Volume 14 Issue 5, 2019, p. 2653-2673

DOI: 10.29228/TurkishStudies.32716

ISSN: 2667-5609

Skopje/MACEDONIA-Ankara/TURKEY

ResearchArticle / Araştırma Makalesi

ArticleInfo/Makale Bilgisi

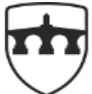

INTERNATIONAL BALKAN UNIVERSITY

EXCELLENCE FOR THE FUTURE IBU.EDU.MK

\Accepted/Kabul: 15.10 .2019

This article was checked by iThenticate.

\title{
DİCK VE CAREY ÖĞRETIMM TASARIMI'NA GÖRE DÜZENLENEN ÖĞRETIMM İLKE VE YÖNTEMLERİ DERSI HAKKINDA ÖĞRETMEN ADAYLARININ GÖRÜŞLERİ (BURSA ULUDAĞ ÜNV. ÖRNEĞİ)
}

\author{
Ersin ŞAHINN*
}

\begin{abstract}
öz
Araştırmanın amacı Öğretim ilke ve yöntemleri dersini Dick ve Carey Öğretim tasarımı modelinin işlenişine ve geleneksel işlenişe göre takip eden Eğitim Fakültesi öğretmen adaylarının görüşlerinin bazı değişkenler açısından incelenmesidir. Araştırmanın örneklemini Uludağ Üniversitesi, Eğitim Fakültesi İngilizce Öğretmenliği ve Sınıf Öğretmenliği programlarına 2016-2017 bahar yarıyılında öğrenim gören toplam 59 ikinci sınıf öğretmen adayı ve dersi yürüten 8 öğretim elemanı oluşturmuştur. Araştırmada veriler adaylar ve öğretim elamanları için görüşme formları, çoklu zeka alanları dağılımı ölçeği, son test arac1 ve öğretimi değerlendirme anketi kullanılmıştır. Veriler SPSS 13 programı ile analiz edilerek görüşme formlarından, çoklu zeka dağılım ölçeğinden ve öğretimi değerlendirme anketinden elde edilen veriler merkezi dağılım ölçüleri ile son test sonuçlarına göre deney ve kontrol gruplarının akademik başarılarının karşılaştırılması için ise Mann Whitney-Utesti kullanılmıştır. Araştırma sonuçlarına göre; öğretmen adayları bu derste en çok "hedef ve davranış ayrımı, yazımı ve aşamalı olarak sıraya koyma" ve "plan çeşitlerini öğeleri bakımından birbirinden ayırma” konularını öğrenmede güçlük çekmektedirler. Deney grubundaki adayların kontrol grubuna göre daha çok sözel, görsel kinestetik ve sosyal zeka alanlarında gelişmiş oldukları tespit edilmiştir. Deney grubu ile kontrol grubu adayların akademik başarıları arasında deney grubu lehine anlamlı bir farl111k bulunmuştur $(\mathrm{P}<.001)$. Deney grubu adaylarının dersin öğretimini değerlendirme görüşleri kontrol grubuna göre ise daha olumludur.
\end{abstract}


Anahtar Kelimeler: Öğretim tasarımı, Çoklu zeka, Öğretmen
adayı.

\title{
VIEWS OF PRESERVICE TEACHERS ABOUT THE TEACHING PRINCIPLES AND METHODS COURSE ORGANIZED ACCORDING TO THE DICK AND CAREY MODEL (SAMPLE OF BURSA ULUDAG UNIVERSITY)
}

\begin{abstract}
The aim of this study was to examine in terms of some variables the views of preservice teachers in the Education Faculty who were taking the teaching principles and methods course according to the instructional process of the Dick and Carey model and according to the traditional instructional process. The sample of this research consisted of a total of 59 second-grade preservice teachers studying in the English Language Teaching and Primary Education Teaching programs of the Faculty of Education at Uludag University during the spring semester of the 2016-2017 academic year, and 8 instructors delivering the course. For collecting the research data, interview forms for candidates and instructors, a scale for distribution of multiple intelligence areas, a post-test tool and teaching evaluation questionnaire were used. The data were analyzed with the SPSS 13 program. Data obtained from the interview forms, multiple intelligence distribution scale and teaching evaluation questionnaire were analyzed according to central distribution measures and post-test results, while the Mann-Whitney U-test was used for comparison of the academic achievement of the experimental and control groups. According to the research results, the teacher candidates said that for this course, they had most difficulty in learning "distinguishing, writing and incremental ordering of target and behavior" and "differentiating plan types in terms of their elements". It was determined that the candidates in the experimental group showed more development in the verbal, visual, kinesthetic and social intelligence areas than those in the control group. A significant difference in academic achievement between candidates in the experimental and control groups was found in favor of the experimental group $(\mathrm{U}=85.5, \mathrm{P}<.001)$. Candidates in the experimental group had more positive views regarding evaluation of the course instruction than those in the control group.
\end{abstract}

\section{STRUCTURED ABSTRACT}

\section{Aim and Importance of the Study}

The aim of this study was to examine, in terms of some variables, the academic achievement and views on evaluation of course teaching of preservice teachers in the Education Faculty who were taking the teaching principles and methods course according to the instructional process of the Dick and Carey model and according to the traditional instructional process. It was considered that the fact that the developmental stages of the instruction in the Dick and Carey instructional design model are integrative as a systematic process and

Turkish Studies - Educational Sciences

Volume 14 Issue 5, 2019 
are learner-centered, would be very effective especially for teacher candidates taking the teaching principles and methods course to foresee potential difficulties they might encounter in the planning and plan types unit and to take precautions accordingly. Moreover, it was also considered important for the instruction to be implemented within one unit of the course because it was thought that instruction organized to suit the design stages would improve the preservice teachers' academic achievement.

\section{Method}

A descriptive and experimental research model was used together in the study. Firstly, it was decided which subjects of the teaching principles and methods course the preservice teachers had difficulty with, whether or not this situation could be dealt with as an instruction problem and whether or not a solution would be necessary, and, in order to determine the reasons for these, learner, instructor, aim, content, measurement and evaluation analyses were made. Selection of the study group of the research was determined using the criterion sampling strategy. Based on the criteria, the study group consisted of second-grade preservice teachers attending the Teaching of English as a Foreign Language and the Primary Education Teaching programs during the spring semester of the 2016-2017 academic year, and 8 instructors delivering the course. For determining the experimental and control groups, the random assignment method was adopted, and so 29 students in the English Teaching group were assigned to the control group, while 30 students in the Primary Teaching group were appointed to the experimental group.

\section{Data Collection Tools and Data Analysis}

In the study, in order for the stages of the relevant instructional design model to be implemented, an interview form, prepared with the aim of determining the subject headings in which the candidates experienced the most problems while studying this course, was applied. To determine the dominant and non-dominant types of intelligence of the teacher candidates in the experimental and control groups, the 5point Likert-type "Multiple Intelligence Areas Evaluation Scale" developed by Gülssen (2015) was applied. For the instructors delivering the teaching principles and methods course, an individual interview form was used. With the aim of determining to what extent the instruction process carried out was successful in solving the problems experienced by the students during the instruction and whether it led to any difference compared to the case of teaching the subject with the traditional method, the post-test experimental and control group model was used by means of the Mann-Whitney U-test. In the assessment section, the post-test tool was applied to the candidates in the experimental and control groups with the aim of determining their skills related to the teaching principles and methods course. To calculate the reliability of the achievement test to be applied to the experimental and control groups at the end of the instruction, the test items were made up of 25 questions chosen from the question pool for the planning in teaching lesson created by the instructors. The tool was applied to a total of 55 teacher candidates in the second grade of the Art Teaching department. According to the data obtained, the calculated Cronbach's Alpha reliability coefficient was found to be .964 . Accordingly, it was 
decided to use the measurement tool at the end of the instruction without any changes. At the end of the instruction of the planning and plan types subject of the teaching principles and methods course, a 5point Likert-type "teaching evaluation questionnaire" made up of a total of 30 items was applied to the students in the control and experimental groups. The items in the questionnaire are scored in a positive direction. Regarding structural validity of the scale, a single-factor structure with a total variance of $37.504 \%$ was obtained. The total Cronbach's Alpha reliability coefficient of .9158 for the items was found sufficient, and students' responses for each item were collected and interpreted by expressing them as frequency and percentage distributions. Analysis of the research data was made using SPSS 22.0 software.

\section{Findings}

\section{Findings Related to the First Sub-Problem of the Research}

According to the results of the analysis of the views of the thirdand fourth-grade preservice teachers in the English Teaching and Primary Teaching departments who had taken the teaching principles and methods course, the most difficult subjects for the candidates were stated to be: distinguishing, writing and incremental ordering of target and behavior; differentiating plan types in terms of their elements; assessing examples of prepared daily lesson plans; explaining the importance of planning; and defining different plans, in that order.

\section{Findings Related to the Second Sub-Problem of the Research}

It can be said that the candidates in the experimental group showed more development in the verbal, visual, kinesthetic and social intelligence areas than those in the control group. However, since the traditional teaching method was to be used in the control group, the data obtained from the students' intelligence profiles were not used. On the other hand, when considering that the candidates in the control group showed development in the verbal-linguistic field, it can be said that they would be able to benefit from traditional instruction.

\section{Findings Related to the Third Sub-Problem of the Research}

The candidates stated that to attract their attention when entering the lesson, it was necessary for the importance of the subject of planning and plan types to be emphasized in terms of managing and monitoring the teaching profession, that it was important for the necessary explanations to be made in order for students to be separately motivated about the importance of the subject to be dealt with, and that it was important for students to be reminded about prerequisite information related to this subject. They also stated that for this purpose, students needed to be given the opportunity to examine samples of blank plans.

\section{Findings Related to the Fourth Sub-Problem of the Research}

Following the intervention, a significant difference in academic achievement between the candidates in the experimental group who participated in the class in which the planning and plan types subjects of the unit related to planning educational activities in the teaching principles and methods course was delivered according to the Dick and 
Carey instructional design model, and the candidates in the control group who did not take part in this program and who participated in the class in which the same subjects were taught according to the traditional teaching model, was found in favor of the candidates in the experimental group $(\mathrm{U}=85.5, \mathrm{P}<.001)$.

\section{Findings Related to the Fifth Sub-Problem of the Research}

With regard to the instruction of the planning and plan types subject in the teaching principles and methods course, all the candidates in the experimental group $(100 \%)$ reported that they agreed completely with the view that tools and materials were used to concretize the lesson, almost all of them (93\%) stated that objectives and outcomes were clearly explained, $93 \%$ of them reported that achievement of aims was focused on throughout the lesson, $87 \%$ said that tools and materials were suited to the subject, $87 \%$ reported that the environment in class was suitable for organizing cooperation, while $87 \%$ agreed with the view that the questions in the achievement test were suited to the subjects. As for the candidates in the control group, $79.3 \%$ stated that they partially agreed that the seating arrangement in the classroom was relaxing, $75.8 \%$ reported that they did not agree with the view that the environment in class was suitable for organizing cooperation, $72.4 \%$ said that they partially agreed with the view that speed adjustment was made by assessing the situation of the class, $68.9 \%$ said that they did not agree with the view that precautions were taken in time against problems during discussions, while 65.5\% reported that they completely agreed with the view that the subjects were presented by following a fluent and logical order.

\section{Conclusion and Recommendations}

Differences were determined between the preservice teachers in the experimental and control groups regarding both their success in class and their views related to assessment of the instruction. It can be said that there was a parallel between the lower academic achievement and negative views related to the instruction in the control group, whereas the experimental group, whose academic achievement level was higher, held more positive views regarding the instruction. It was revealed that the activities organized in accordance with the Dick and Carey instructional design model made a positive contribution to better learning of the subjects in which the teacher candidates had problems, that they positively increased their academic success and that compared to traditional instruction, the effectiveness of the instruction also left positive impressions on the teacher candidates. Therefore, it can be recommended that the stages of the Dick and Carey instructional design model be used for teaching subjects that preservice teachers in other professional teaching knowledge courses have difficulty with. For teaching subjects belonging to other courses included in higher education programs, recommendations should be made by examining what type of instructional designs will be most effective for preservice teachers. teachers

Keywords: Instructional design, multiple intelligence, preservice 


\section{Giriş}

Günümüzde bireysel öğrenenlerin yalnızca yetenekleri üzerine odaklanan geleneksel öğretim sınıflarındaki planlama ve uygulamaların aksine modern öğretim yaklaşımları; öğrenciler, materyaller ve öğretmenlerle birlikte daha uygun amaçları içeren bütünleştirilmiş bir öğrenme çevresini ve birbiriyle bağlantılı sistemi gerekli kılmaktadır. Etkili bir öğretim sistemini hayata geçirmek için ise, her bir öğenin sağlayacağı katkıya, değerlendirilmeye ve öğrenme öğretme etkinliklerinin nasıl planlanarak daha verimli biçimde öğrenenlere katkı getirebileceğine dair kararları almak gerekmektedir. Bu konuda öneri getiren birçok öğretim modelleri olmasına karşın modellerin sadece bir bölümü öğretim sisteminin geliştirilmesi üzerine tasarımlarını açıklamaktadırlar.

Öğretim tasarımı bir süreç olarak, öğretimin gerçekleşmesi için gereken görevlerin tanımlanmasını ve öğretim programına konulmasını içerir (İpek, 2002; Esmer, 2018). Dick ve Carey Öğretim Tasarımı Modeli de bu özelliğe sahip en iyi bilinen hem teori hem de uygulamaya dayalı (Jones ve Richey, 2000) "sistematik tasarım" anlayışı ile bilişsel ve davranışçı kuram temelinde yapılandırılmış bir modeldir (Winn,1993; Akbulut, 2007;Dicks ve vd., 2005, Fotiyeva, 2013). Bu model yaygın olarak kabul görmüştür (Braden, 1996). Hatta öğretim tasarımı araştırmacılarının öncelikle bu modeli dikkate alarak tasarımlarını düzenlediklerini savunan görüşler vardır (Dick, 1996). $\mathrm{Bu}$ modelin dayandığı öğretim teorisine göre; öğretmenler, öğrenciler, materyaller ve öğretim aktiviteleri ile öğrenme performansı çevresi birbirleriyle etkileşim halindedir (Swapnil, 2008) ve öğrenenlere sunulan öğretim ortamı ile kazanılan davranışlar arasında anlamlı bir ilişki vardır. (Dick,Carey; Carey, 2001). Bu model on aşamadan oluşmaktadır (DickCarey, 2004;Carey, 2009). Modeldeki birinci aşama öğrenenlerdeki istendik özelliklerin belirlendiği öğretim amaçları üzerine odaklanır (Gagne, Briggs, ve Wagner, 1992). Bu noktada ihtiyaç analizi de yapılır. İkinci aşamada öğretim analizi yapılarak, öğrenenlerin ihtiyaç duydukları bilgi, beceri ve tutumları belirlenir. Üçüncü aşamada öğrenenlerin analizi ve içerik analizi tespit edilir. Özellikle öğrenenlerin uzamsal sözel ve zihinsel becerilerinin belirlenmesine çalış1lır.Dördüncü aşamada ise detaylandırılmış performans hedefleri üzerine odaklanılır. Bunun amacı uygun öğrenme koşullarında sürdürülmesi planlanan dersler de öğrencilerin kendi kendilerine çalışma becerilerini nasıl geliştirebilecekleri ve onların hangi düzey performanslarının ölçülmesi gerektiğine karar verilir. Beşinci aşamada, öğrencilerin öğrenme sonuçlarının gözden geçirilmesi ve yeni öğrenme becerileri için gereken becerilere önceden ne düzeyde sahip oldukları ortaya konur. Bu amaçla belirlenen materyal ve dokümanlar hem kendileri ile hem de okul yöneticileri ve veliler ile paylaşılır. Altıncı aşama da öğretim aktivitelerini belirleme ve kullanılması gereken öğretim stratejileri, yöntemler ve teknikler belirlenir. Yedinci aşama da ise öğretim materyalleri belirlenir. Bu materyaller, öğretmen rehberliği ,öğrenci modülleri, tv, bilgisayar temelli çoklu öğeler ,uzaktan öğrenme için web sayfaları ve yazılımlar gibi tüm öğeleri içermektedir (Gagne vd., 1992;Matthew2000; Briggs vd., 1991). Sekizinci aşamada ise biçimsel değerlendirme üzerine odaklanılır. Buradaki amaç ögrenciler için kullanılan öğretim materyalleri için veri sağlamak ve mümkün olduğu kadar çok öğrencinin öğrenme eksikliklerini kesin ölçütlere göre açığa çıkarmak (Lebow,1993) ve ögrretimi daha etkili hale getirmektir. (Matthew 2000;Cliffs vd., 1994).Küçük grup, bire bir ve ortak alan uygulamalarının değerlendirmeleri yapılır (Reiser ve Dempsey, 2002; 2012). Dokuzuncu aşama, öğretim süreci boyunca ortaya çıkan sorun ve eksikliklerini ortaya koyarak gerekli önlemleri almak ve süreci geliştirmek için yapılan biçimsel bir değerlendirmedir. Son aşamada ise öğretimin etkililiği ve verimliliğini belirgin biçimde ortaya koyan sonuç değerlendirme üzerine odaklanılır. $\mathrm{Bu}$ modelin özellikle "öğrenenin davranışlarını önceden tahmin etmekle gerçekleştirilebileceğini” görüşünün aksine, McGriffe (2000)'e göre davranışlar önceden tahmin edilemez.Bu eleştiriye rağmen Dick ve Carey modeli geniş bir kabul ve uygulama alanı bulmuştur. Gustafson (1993) ve Branch (1994), bu modelin eğitim dişında endüstri, hükümet, askeri gibi, birçok iş alanında da kullanılan temel bir tasarım süreci olduğunu belirtmişlerdir. Okubo ve Arkadaşları (2016) tarafından mühendislik alanında çalışanların işteki problem çözme becerilerinin geliştirilmesi üzerine yapılan araştırmada da kullanılan bu modelin verimlilik bakımından önemli ölçüde etkili 
olduğu vurgulanmıştır. Bu model aynı zamanda teknolojik olarak bilgisayarın eğitime uygulanmasını etkilemiştir. Modelin uzaktan eğitime uygulanabilirliği konusunda da görüş birliğine varılmıştır.Öğretmenlerin belli bir öğretim tasarım modelini takip etmeden öğrenme ve öğretme süreçlerini yapılandırma çabaları hakkında ve öğretim hedeflerini belirleme, planlama, materyal geliştirme, uygulama, analiz ve değerlendirme gibi becerilerinin eksikliğinin yanı sıra buna yol açan etmenlerle ilişkili olarak alanyazında bir çok araştırma yapılmıştır (Clemente ve Martin 1990; Park, 2007;.Moallem, 1998; Young vd.,1998; Karaca vd., 2008, Kircshner ve Van Merrienboer, 2002; Han, 2009). $\mathrm{Bu}$ araştırmaların sonuçları ise çoğunlukla öğretmenlerin belirli öğretim tasarımları çerçevesinde öğretim etkinliklerini planlama ve yürütmelerini önermektedir.

Öğretim ilke ve yöntemleri dersi yükseköğretimde, Eğitim Fakültelerinde, öğretmen adaylarının hizmet öncesi eğitim aşamasında öğretmenlik meslek formasyonu kazanmaları amacıyla geliştirilen derslerden birisidir. Yüksek Öğretim Kurumu'nun Kur tanımına göre (YÖK, 2007), "Öğretim İlke ve Yöntemleri” dersi, öğretimle ilgili temel kavramlar, öğrenme ve öğretim ilkeleri, öğretimde planlı çalışmanın önemi ve yararları, öğretimin planlanması (ünitelendirilmiş yıllık plan, günlük plan ve etkinlik örnekleri), öğrenme ve öğretim stratejileri, öğretim yöntem ve teknikleri, bunların uygulama ile ilişkisi, öğretim araç ve gereçleri, öğretim hizmetinin niteliğini artırmada öğretmenin görev ve sorumlulukları ve öğretmen yeterliklerini içeren bir içerikten oluşmalıdır. Nitekim Kılıç ve Acat (2007) tarafından yapılan araştırma sonuçları da, öğretmen adaylarının uygulamaya dayalı dersleri öğretmenlik becerileri açısından daha işe yarar bulduklarını ortaya çıkarmıştır. Ayrıca, Bay ve Karakaya (2009) tarafindan yapılan deneysel araştırma sonuçlarına göre ise, öğretmen yetiştirme programındaki öğretim ilke ve yöntemleri dersinde yapılandırmacı anlayışa dayanan, öğrencilerin aktif katılımını sağlayan yaklaşımın, konu merkezli program yaklaşımına dayanan duruma oranla sözü edilen dersin üst düzey becerileri açısından daha etkili olduğu belirlenmiştir. Güney ve Semerci (2009)'ye göre ise, öğretimde planlama ve değerlendirme dersinin mikro öğretime dayanan uygulamalı etkinliklerle işlenmesinin, geleneksel işlenişe göre adayların yansıtıcı düşünme düzeylerini geliştirmeleri açısından daha etkili olduğu belirlenmiştir.

$\mathrm{Bu}$ görüşler 1şı̆̆ında Dick ve Carey tasarım modelinin yukarıda açıklanan uygulama aşamalarının öğretim ilke ve yöntemleri dersinin ilenişi ile uyumlu olacağı düşünülmüş ve dersin "Planlama ve Plan Çeşitleri" ünitesi içerisinde modelin bazı aşamaları dikkate alınarak aşağıda yer alan planlamaya uygun olarak yapılmasına karar verilmiştir;

Tablo1: Dick ve Carey Tasarım Modelinin Öğretim İlke ve Yöntemleri Dersine Yönelik Uygulama Aşamaları

\begin{tabular}{|c|c|c|}
\hline Faaliyet & İçerik & Süre \\
\hline $\begin{array}{l}\text { I. Öğretimin Gözden Geçirilmesi } \\
\text { (İhtiyaç Analizi) }\end{array}$ & $\begin{array}{l}\text { 1. Öğrenen analizi } \\
\text { 2.Öğretim elemanı analizi } \\
\text { 3. İçerik analizi } \\
\text { 4. Hedef -Davranış analizi } \\
\text { 5.Ölçme ve değerlendirme analizi }\end{array}$ & 2 Hafta \\
\hline $\begin{array}{l}\text { II. Öğretim Stratejileri } \\
\text { Geliştirme }\end{array}$ & $\begin{array}{l}\text { 1. İceriğin dizilimi } \\
\text { 2. Ö̆ğretim stratejisi seçimi } \\
\text { 3. Arac-gerec secimi }\end{array}$ & $3 \mathrm{Hafta}$ \\
\hline III. Materyal Geliştirme & $\begin{array}{l}\text { 1. Stratejiye uygun materyal seçme } \\
\text { 2. Materyal geliştirme }\end{array}$ & 2 Hafta \\
\hline IV. Değerlendirme & $\begin{array}{l}\text { 1. Biçimsel Değerlendirme } \\
\text { 2.Sonuç Değerlendirme }\end{array}$ & $2 \mathrm{Hafta}$ \\
\hline
\end{tabular}

Bu doğrultuda; Dick ve Carey Öğretim tasarımı modelinin öğretim ilke ve yöntemleri dersini alan Eğitim Fakültesi öğretmen adaylarının akademik başarıları ve dersin öğretimini değerlendirme görüşleri üzerindeki etkisini belirlemek amacıyla aşağıdaki sorulara yanıt aranmıştır; 
1. Öğretim ilke ve yöntemleri dersini Üst gruplarda almış olan İngilizce ve Sınıf Öğretmenliği programına devam eden adayların en çok sorun yaşadıkları konuların sınıf düzeylerine göre görüşlerinin dağılımı nasıldır?

2. Öğretmen adaylarının farklı zeka alanlarının dağılımı nasıldır?

3. Öğretim ilke ve yöntemleri dersinde öğretim elemanlarının deney grubu üzerinde uygulanacak stratejiler, kullanılacak materyaller ve değerlendirme araçları hakkındaki görüşleri nelerdir?

4. Öğretim ilke ve yöntemleri dersini takip eden deney grubu ve kontrol grubu öğretmen adaylarının akademik başarı son test puanları arasında anlamlı farklılık var mıdır?

5. Öğretim ilke ve yöntemleri dersinin işlenişine göre öğretmen adaylarının ders öğretimini değerlendirme görüşlerinin dağılımları nasıldır?

\section{Araştırmanın Önemi}

Öğretmen adayları mezuniyetlerinden sonra atandıkları ilk yıllarında yaşadıkları uyum sorunları yanında ders planlarını takip etme, hazırlama ve yürütme gibi beceriler de de eksiklik görmektedirler. Bu sebeple bu araştırmada da, Dick ve Carey öğretim tasarımı modelinin öğretimi geliştirici aşamalarının sistematik bir süreç olarak bütünleştirici ve öğrenen merkezli olmasının, özellikle öğretim ilke ve yöntemleri dersini takip eden öğretmen adaylarının planlama ve plan çeșitleri ünitesi içinde yaşayabilecekleri olası sorunları önceden fark ederek önlem alabilmeleri için oldukça etkili olacağı düşünülmektedir. Ayrıca tasarım aşamalarına uygun düzenlenen öğretimin adayların akademik başarılarını arttıracağı da düşünüldüğü için dersin bir ünitesi içerisinde uygulanması önemli bulunmuş ve araştırma Uludağ Üniversitesi, Eğitim Fakültesi, İngilizce Öğretmenliği ve Sınıf Öğretmenliği programına devam eden öğretmen adayları ile ve Öğretim ilke ve yöntemleri dersinin bir ünitesi ile sınırlandırılmıştır.

Öğretim ilke ve yöntemleri dersi öğretmen yetiștiren bütün alanlarda okutulması zorunlu olan dersler arasında yer almıştır. Dersin içeriği öğretmen adaylarının yapacakları çalışmaları belirlenme, izlenme ve değerlendirilmeyi sistematik bir biçimde sürdürmeyi gerektirmektedir. $\mathrm{Bu}$ sebeple bu araştırma da eğitim fakültesi öğretmen adaylarının akademik başarıları ve dersin öğretimini değerlendirme görüşleri belirlenerek bazı değişkenler bakımından incelenmiştir.

\section{Yöntem}

Araştırmada betimsel ve deneysel çalışma modeli birlikte kullanılmıştır. Öncelikle öğretmen adaylarının öğretim ilke ve yöntemleri dersinin hangi konuların da zorlandıkları ve bu durumun bir öğretim problemi olarak ele alınıp alınamayacağına ve bir çözümün gerekli olup olamayacağına karar verilmiş ve bunların nedenlerini saptamak üzere öğrenen, öğretim elemanı, amaç, içerik, ölçme ve değerlendirme analizi yapılmıştır.

\section{Çalışma Grubu}

Araştırmanın çalışma grubu, problemle ilgili olarak belirlenen niteliklere sahip kişiler, olaylar, nesneler ya da durumlardan oluşturulması(Büyüköztürk, 2012) istendiğinden amaçsal örnekleme stratejilerinden biri olan ölçüt örnekleme ile belirlenmiştir. Çalışma grubu ölçüte dayalı olarak Uludağ Üniversitesi, Eğitim Fakültesi, Yabancı Diller İngilizce Öğretmenliği ve İlköğretim Sınıf Öğretmenliği programlarına 2016-2017 bahar yarıyılı öğretim döneminde devam eden 2.sınıf öğretmen adayları ve dersi yürüten 8 öğretim elemanıdır. Deney ve kontrol gruplarının belirlenmesinde yansız atama yöntemi benimsenmiş ve İngilizce öğretmenliği grubundaki 29 öğrenci kontrol, Sınıf öğretmenliği grubundaki 30 ögrenci ise deney grubu olarak belirlenmiştir. 


\begin{tabular}{|c|c|c|c|c|c|}
\hline \multicolumn{6}{|c|}{ Tablo 2: Çalışma Grubunun Özellikleri } \\
\hline \multirow[t]{3}{*}{ Branşlar } & \multicolumn{4}{|c|}{ Cinsiyet } & \multirow{3}{*}{$\begin{array}{l}\text { Toplam } \\
\mathrm{f}\end{array}$} \\
\hline & & & & & \\
\hline & f & $\%$ & $\mathrm{f}$ & $\%$ & \\
\hline İngilizce & 5 & 36 & 24 & 54 & 29 \\
\hline Sınıf Öğretmenliği & 9 & 64 & 21 & 46 & 30 \\
\hline Toplam & 14 & 100 & 45 & 100 & 59 \\
\hline
\end{tabular}

Tablo 2'ye göre araştırmaya katılan İngilizce kontrol grubu adayların \%54'ü kadın, \% 36's1 erkek, Sınıf öğretmenliği deney grubu adaylarının ise \% 64 'ü erkek, \% 46'sı kadındır.

\section{Veri Toplama Araçları Ve Verilerin Analizi}

Araştırmada ilgili öğretim tasarımı modelinin aşamalarının uygulanabilmesi için öncelikle, İngilizce öğretmenliği ve sınıf öğretmenliği programlarına devam eden bir üst seviyedeki 3.sınıf adaylarından rastgele seçilen 10 kişive 4.sınıf adaylarından rastgele seçilen 10 kişi ile bu dersin öğrenilmesi sırasında daha çok sorun yaşadıkları konu başlıklarını tespit etmek amacıyla hazırlanan görüşme formu uygulanmıştır.

Deney ve kontrol grubunda yer alan öğretmen adaylarının baskın olan ve olmayan zeka tiplerinin belirlenmesi için Gülşen(2015) tarafından geliştirilen 5'li likert tipi "Çoklu Zeka Alanları Değerlendirme Ölçeği” uygulanmıştır. Sekiz zekâ alanına yönelik 80 maddeden oluşan formun bütün halinde Cronbach's Alpha $(\alpha)$ değeri ise, 0,965 iken farklı örneklem grubu üzerinde uygulanan deneme formundan elde edilen maddeler toplam Cronbach's Alpha $(\alpha)$ değeri ise, 0,917 olarak hesaplanmış ve mevcut hali ile güvenilir bir araç olarak araştırma da kullanılabileceğine karar verilmiştir.

Öğretim ilke ve yöntemleri dersini yürüten öğretim elemanlarının; dersin öğretimi sırasında daha çok zorluk çektikleri konuları, adayların öğrenmede güçlük çektikleri konuları, öğretim ortamının analizine ilişkin olarak mevcut teknik alt yapı ve donanım özellikleri, dersin öğretimini etkileyen diğer hususlar ve konunun öğretiminde deney grubu için gerekli öğretim stratejilerinin belirlendiği bireysel görüşme formu kullanılmıştır.

Görüşme formlarından elde edilen verilere ait sonuçlar analiz edilerek öğretim ile ilgili problemli konu tespit edilmiş ve Öğretim ilke ve yöntemleri dersinde öğretmen adaylarının sorun yaşadıkları konulara ilişkin öğretim sorununu çözmek için, ilgili öğretim tasarımı modeli aşamaları dikkate alınarak hazırlanan bir öğretim süreci uygulamaya sokulmuştur. Bu sürecin öğrencilerin öğretim sırasında yaşadıkları sorunları çözmede ne ölçüde başarılı olup olmadığı ve konunun geleneksel öğretim modeli ile işlenmesi durumunda herhangi bir farklılığa yol açıp açmadığının belirlenmesi amaciyla deneme modellerinden deney ve kontrol gruplu son test model (Mann Whitney U-testi) kullanılmışırı. Modelin uygulanması esasına dayalı olarak, deney ve kontrol gruplarının belirlenmesinde yansız atama yöntemi benimsenmiş, deney grubu üzerinde Dick ve Carey öğretim tasarımı modeli aşamalarına uygun bir öğretim yapılırken, kontrol grubu üzerinde geleneksel öğretim uygulaması yapılmıştır. Başta belirlenmiş olan hedef ve davranış analizine dayalı olarak, deney ve kontrol grubu adayları üzerinde gerçekleştirilen öğretim uygulaması sonuçları ile belirlenmiş öğrenci kazanımları arasında bir fark olup olmadığının incelenmesi yapılmıştır. Bunun için ölçmedeğerlendirme analiz süreci ile ilgili olarak hazırlanmış olan belirtke tablosuyla öğretim hedefleri arasından testlerde kullanılacak, soru maddelerinin seçimi yapılmıştır.

Değerlendirme kısmında deney ve kontrol grubunda yer alan adaylara, öğretim ilke ve yöntemleri dersi ile ilgili konularda becerilerini belirlemek amacıyla son test aracı uygulanmıştır. Test maddeleri, deney ve kontrol grubuna öğretim sonunda uygulanacak başarı testinin güvenilirliğini hesaplamak üzere, öğretim elemanları tarafından oluşturulmuş öğretimde planlama dersine ait soru 
havuzundan seçilen 25 sorudan oluşmuştur. Araç, Resim-İş eğimi anabilim dalı 2.sınıf düzeyinde toplam 55 adaya uygulanmıştır. Elde edilen verilerden hesaplanan Cronbach's Alpha güvenilirlik katsayıs1 .96,4 olarak bulunmuştur. Böylece ölçme aracının öğretim sonunda olduğu gibi kullanılmasına karar verilmiştir.

Öğretim ilke ve yöntemleri dersinin planlama ve plan çeşitleri konusunun öğretimi sonunda kontrol ve deney gruplarında yer alan öğrencilere toplam 30 maddeden oluşan "ders öğretimini değerlendirme anketi” uygulanmıştır. Ankette yer alan maddeler pozitif yönde ifadelendirilmiştir. Anketin yapı geçerliğine ait toplam varyans değeri \%37.504 bulunarak tek faktörlü toplanmıştır. Maddelerin toplam Cronbach's Alpha güvenilirlik katsayıs1 .9158 ile yeterli bulunmuş, her bir maddeye ilişkin öğrenci cevapları toplanarak frekans ve yüzde dağılımları biçiminde düzenlenerek yorumlanmıştır.

\section{Bulgular ve tartışma}

\section{Araştırmanın Birinci Alt Problemine İlişkin Bulgular}

Öğretmen adaylarının öğretim ilke ve yöntemlerine dersine ait zor buldukları konular sınıf düzeylerine incelenerek aşağıdaki gibi belirlenmiştir;

Tablo 3: Adayların Öğretim İlke ve Yöntemleri Dersine Ait Zor Buldukları Konulara Ait Görüşlerinin

\begin{tabular}{|c|c|c|c|c|c|c|}
\hline \multicolumn{7}{|c|}{ Dağılımı } \\
\hline \multirow[t]{2}{*}{ Görüş } & \multicolumn{2}{|c|}{$\begin{array}{l}\text { 3. Sinif } \\
\mathrm{n}=10\end{array}$} & \multicolumn{2}{|c|}{$\begin{array}{l}\text { 4.Sinif } \\
\mathrm{n}=10\end{array}$} & \multicolumn{2}{|c|}{$\begin{array}{l}\text { Toplam } \\
\mathrm{n}=20\end{array}$} \\
\hline & $\mathrm{f \%}$ & & $\mathrm{f} \%$ & & $\mathrm{f \%}$ & \\
\hline Farklı plan tanımlarını yapma & 7 & 70 & 5 & 50 & 12 & 60 \\
\hline Plan yapmanın önemini açılama & 6 & 60 & 7 & 70 & 13 & 65 \\
\hline Plan çeşitlerini birbirinden ayırma & 9 & 90 & 8 & 80 & 17 & 85 \\
\hline $\begin{array}{l}\text { Hedef ve davranış ayrımı, yazımı ve aşamalı } \\
\text { olarak sıraya koyma }\end{array}$ & 10 & 100 & 9 & 90 & 19 & 95 \\
\hline $\begin{array}{l}\text { Hazırlanmış olan günlük ders planı örneklerini } \\
\text { değerlendirme }\end{array}$ & 8 & 80 & 9 & 90 & 17 & 85 \\
\hline Öğretim yöntemlerinin farklılıkları & 3 & 30 & 2 & 20 & 5 & 25 \\
\hline İletişim sürecinin öğeleri & 4 & 40 & 4 & 40 & 8 & 40 \\
\hline Program geliştirme aşamaları & 1 & 10 & 2 & 20 & 3 & 15 \\
\hline
\end{tabular}

Tablo 3'de görüldüğü üzere, daha önceki yıllarda Öğretim ilke ve yöntemleri dersini almış olan İngilizce Öğretmenliği ve Sınıf Öğretmenliği,3. ve 4. sınıf öğretmen adaylarının görüşlerinin analizi sonuçlarına göre, adaylar zor konuları sırası ile;

1. Hedef ve davranış ayrımı, yazımı ve aşamalı olarak sıraya koyma

2. Plan çeşitlerini öğeleri bakımından birbirinden ayırma

3. Hazırlanmış olan günlük ders planı örneklerini değerlendirme

4. Plan yapmanın önemini açıklama

5. Farklı planların tanımlarını yapma olarak belirtmişlerdir.

\section{Araştırmanın İkinci Alt Problemine İlişkin Bulgular}

Deney ve kontrol grubunda yer alan öğrencilere uygulanan Çoklu Zeka Anketi sonuçlarına göre öğrencilerin baskın olan ve daha zayıf olan zeka alanlarına ilişkin dağılım aşağıdaki tabloda verilmiştir. 


\begin{tabular}{|c|c|c|c|c|c|c|c|c|c|}
\hline \multicolumn{10}{|c|}{ Tablo 4: Adayların Baskın ve Zayıf Zeka Alanlarının Dağılımı } \\
\hline \multirow[b]{2}{*}{ Gruplar } & \multirow[b]{2}{*}{ Dereceler } & \multicolumn{8}{|c|}{ Zeka Alanları } \\
\hline & & $\begin{array}{l}\text { Sözel } \\
\text { Dilsel } \\
\end{array}$ & $\begin{array}{c}\text { Mantıksal } \\
\text { Matematiksel }\end{array}$ & Kinestetik & Görsel & Müzikal & Sosyal & Doğac1 & Özedönük \\
\hline \multirow{5}{*}{$\begin{array}{l}\text { Deney } \\
\text { grubu }\end{array}$} & Çok gelişmiş & & & & 12 & 1 & & 5 & \\
\hline & Gelişmiş & 20 & 8 & 21 & 10 & 4 & 15 & 10 & 1 \\
\hline & Orta gelişmiş & 10 & 12 & 5 & 8 & 8 & 9 & 7 & 12 \\
\hline & Biraz gelişmiş & & 10 & 4 & & 14 & 6 & 4 & 14 \\
\hline & Gelişmemiş & & & & & 3 & & 4 & 3 \\
\hline \multirow{5}{*}{$\begin{array}{l}\text { Kontro } \\
\text { l grubu }\end{array}$} & Çok gelişmiş & 12 & & & 8 & & 4 & & \\
\hline & Gelişmiş & 8 & 5 & 4 & 8 & 6 & 12 & & 11 \\
\hline & Orta gelişmiş & 9 & 12 & 13 & 10 & 17 & 6 & 18 & 9 \\
\hline & Biraz gelişmiş & & 10 & 8 & 3 & 6 & 7 & 7 & 8 \\
\hline & Gelişmemiş & & 2 & 4 & & & & 4 & 1 \\
\hline
\end{tabular}

Tablo 4'e göre, deney grubundaki adayların daha çok sözel, görsel, kinestetik ve sosyal zeka alanlarında gelişmiş olduklarını söyleyebiliriz. Deney grubuna yönelik düzenlenecek öğretim etkinliklerinin özellikle bu zeka alanlarını dikkate alarak oluşturulması sağlanmaya çalışılmıştır. Kontrol grubunda ise geleneksel öğretim yöntemi kullanılacağı için öğrencilerin zeka profillerinden elde edilen veriler kullanılmamıştır. Ancak kontrol grubundaki adayların sözel-dilsel zeka alanında gelişmiş oldukları göz önünde bulundurulursa, geleneksel öğretimden yaralanabilecekleri söylenebilir.

\section{Araştırmanın Üçüncü Alt Problemine İlişkin Bulgular}

Öğretim ilke ve yöntemleri dersinin planlama ve plan çeşitleri konusunun işlenişi sırasında uygulanacak stratejiler, kullanılacak materyaller ve değerlendirme araçları konularında öğretim elemanları ile yapılmış olan görüşme sonuçları şöyledir;

- $\quad$ Öğretim ilke ve yöntemleri dersinin öğretimi sırasında kullanılacak olan stratejilerin, adaylar üzerinde araştırmacı tarafından daha önceden uygulanmış olan çoklu zeka anketi sonuçları ile belirlenmiş olan zeka profillerinin bir ölçüt olarak ele alınarak düzenlenebileceğini belirtmişlerdir.

- $\quad$ Öğretim ilke ve yöntemleri dersinin öğretiminin giriş bölümünde, adayların konular hakkında temel ilke kavram ve genellemeleri tanımaları bakımından sunuş stratejilerine dayalı anlatım ve soru cevap yönteminin kullanılmasının daha uygun olduğunu, dersin ilerleyen gelişme bölümlerinde ise işbirlikçi öğretim stratejilerine dayalı, tartışma yönteminin kullanılmasının daha uygun olacağını belirtmişlerdir. Ayrıca anabilim dalı başkanı, her iki grupta yer alan adayların ileride öğretmen olacakları düşüncesinden hareketle, farklı öğretim yöntemleri ve zengin materyal kullanmanın önemini vurgulamıştır.

- Dersin işlenişi boyunca sunuş stratejisinin kullanımı esnasında adayların bireysel oturma düzeni içerisinde "U" biçiminde, işbirlikçi stratejiler sırasında ise, çember grup düzeni içerisinde oturuş pozisyonu almalarının sağlanmasının öğrenciler üzerinde daha olumlu bir etkiye yol açacağını belirtmişlerdir.

- $\quad$ Adayların derse girişte dikkatlerini çekmek için planlama ve plan çeşitleri konusunun öğretmenlik mesleğinin yürütülmesi ve denetlenmesi açısından öneminin vurgulanması gerektiğini, öğrencilerin işlenecek konunun önemi hakkında ayrıca güdülenmeleri için gerekli açıklamaların yapılması ve öğrencilere bu konu ile ilgili önkoşul bilgilerin hatırlatılmasının önemli olduğunu belirtmişlerdir. Bunun için boş plan örneklerinin öğrencilerin incelemesi için firsat verilmesi gerektiğini de belirtmişlerdir.

- Dersin işlenişi boyunca kullanılması gereken araçları sırasına göre Tahta, Tepegöz,Projeksiyon makinası ve Bilgisayar olarak belirtmişlerdir. 
- $\quad$ Dersin işlenişi sırasında, tahtanın konuya ilişkin temel ilke ,kavram ve genellemelerin (plan, plan çeşitleri, yazım ilkeleri v.b.) tanımlarını yapmada projeksiyon aracının bilgisayar yardımı ile kullanılması biçiminde düzenlenmesi gerektiğini belirtmişlerdir. Ayrıca hedef konusu işlenirken bol örnek göstermenin önemli olduğundan hareketle bunun projeksiyon aracı ile daha rahat yapılabileceğini de eklemiş̧lerdir.

- Dersin işlenişi boyunca yapılacak uygulamalar açısından giriş bölümü için ilk derste Anlatım ve soru-cevap yöntemi kullanılmasını, ikinci dersin son kısmında soru-cevap yöntemi kullanılmasını, üçünü dersin ilk kısmında serbest çalışmaya zaman ayrılmasını, dördüncü dersin başında öğrenci gruplarının belirlenmesi ve grup içi çalışmalara yer verilmesini ve beşinci derste öğrenci gruplarının tartıştırılarak aynı zamanda dönütler alınmasını önermişlerdir.

- Dersin işlenişi sırasında adaylardan alınacak geri dönütlerin öncelikle ilk ve ikinci dersin son $10 \mathrm{dk}$ 'lık bölümlerinde, daha sonra üçüncü dersin son bölümüne yakın $15 \mathrm{dk}$ 'lık bir sürede yapılacak alıştırma çalışmaları sonrasında, dördüncü ve beşinci dersler boyunca ise hem ders içinde grup çalışmaları sırasında adaylar arası tartışma sonlarında hem de son $5 \mathrm{dk}$ 'lık bölümlerde soru-cevap yöntemi kullanılarak yapılmasını önermişlerdir.

- $\quad$ Dersteki öğrenci kazanımlarına ilişkin sonuç değerlendirmeyi yapmada, adayların işbirlikli gruplar halinde ortak bir amaca yönelik çalışmalarını sağlamak için, dersin sonunda bir başarı testi yapılması gerektiğini ve bu testten elde edilen bireysel puanların ortalamasından, grup puanının hesaplanarak en yüksek puan alan grubun üyelerinin final puanlarına 5 puan ekleneceğinin duyurulmasını önermişlerdir. Ayrıca dersin bitiminde adayların ders öğretimini değerlendirmeleri açısından bir anket uygulamasının yapılmasının iyi olacağını belirtmişlerdir.

\section{Araştırmanın Dördüncü Alt Problemine İlişkin Bulgular}

Öğretimde planlama ve değerlendirme dersinin planlama ve plan çeşitleri konusunun öğretimi sonunda deney ve kontrol gruplarında yapılan başarı test sonuçlarına ilişkin U-testine ait bulgular Tablo 5'de verilmiştir.

Tablo 5: Başarı Testi Sonuçlarının Gruplara Göre U-Testi Sonuçları

\begin{tabular}{lccccc}
\hline Grup & $\mathrm{n}$ & Sira Ortalamas1 & Sira Toplamı & $\mathrm{U}$ & $\mathrm{p}$ \\
\hline Deney & 30 & 1.65 & 1249.5 & 85.5 & .000 \\
Kontrol & 29 & 17.95 & 520.5 & & \\
\hline
\end{tabular}

Tablo 5'e göre, Öğretim ilke ve yöntemleri dersinin eğitim ve öğretim etkinliklerinin planlanması ünitesine ait planlama ve plan çeşitleri konularının Dick ve Carey öğretim tasarımı modelinegöre işlendiği derse katılan deney grubu adayları ile, bu programa katılmamış olan ve aynı konuların geleneksel öğretim modeline göre işlendiği derse katılan kontrol grubundaki adayların uygulama sonrasındaki akademik başarıları arasında, deney grubu adaylar lehine anlamlı bir fark bulunmuştur $(\mathrm{U}=85.5, \mathrm{P}<.001)$. Sira ortalamaları dikkate alındığında Dick ve Carey öğretim tasarımı modeline göre işlenen derse katılan deney grubu adayların, bu derse katılmamış olan kontrol grubu adaylarına göre akademik başarı puanları daha yüksek bulunmuştur. Bu bulgunun Dick ve Carey öğretim tasarımı modeline göre planlanan öğretim ilke ve yöntemleri dersinin adayların sorun yaşadıkları konuları öğrenmelerinde ve akademik başarılarını yükseltmede etkili olduğu söylenebilir.

\section{Araştırmanın Beşinci AltProblemine İlişskin Bulgu ve Yorumlar}

Öğretim ilke ve yöntemleri dersinin planlama ve plan çeşitleri konusunun öğretimi sonunda deney ve kontrol gruplarında yer alan öğrencilere uygulanan ders öğretimini değerlendirme anketine ilişkin sonuçlar aşağıda verilmiştir; 
Tablo 6: Deney Grubu Ders Öğretimini Değerlendirme Dağılımı

\begin{tabular}{|c|c|c|c|c|c|c|c|c|c|c|}
\hline & \multicolumn{2}{|c|}{$\begin{array}{c}\text { Tamamen } \\
\text { kat1lyyorum } \\
\text { (1) }\end{array}$} & \multicolumn{2}{|c|}{$\begin{array}{c}\text { Katıliyorum } \\
\text { (2) } \\
\end{array}$} & \multicolumn{2}{|c|}{$\begin{array}{c}\text { K1smen } \\
\text { kat1lyyorum } \\
\text { (3) }\end{array}$} & \multicolumn{2}{|c|}{$\begin{array}{c}\text { Katılmiyorum } \\
(4)\end{array}$} & \multicolumn{2}{|c|}{$\begin{array}{c}\text { Hiç } \\
\text { katılmıyorum } \\
(5)\end{array}$} \\
\hline & $\mathrm{f}$ & $\%$ & $\mathrm{f}$ & $\%$ & $\mathrm{f}$ & $\%$ & $\mathrm{f}$ & $\%$ & $\mathrm{f}$ & $\%$ \\
\hline $\begin{array}{l}\text { 1.Konulara ilişkin hedefler ve kazanımlar açıkça } \\
\text { belirtildi }\end{array}$ & 28 & 93 & 2 & 7 & & & & & & \\
\hline $\begin{array}{l}\text { 2.Konu ile ilgili kavram ve ilkeler açıkça } \\
\text { tanımlandı. }\end{array}$ & 25 & 83 & 5 & 17 & & & & & & \\
\hline 3.Konuyu açıklamak için bol örnekler kullanıldı & 22 & 73 & 2 & 7 & 6 & 20 & & & & \\
\hline $\begin{array}{l}\text { 4.Öğrenciler, derse katılmaları için } \\
\text { yüreklendirildi. }\end{array}$ & 20 & 67 & 6 & 20 & 4 & 13 & & & & \\
\hline $\begin{array}{l}\text { 5.Konu hakkında düşünceyi harekete geçirici } \\
\text { sorular soruldu. }\end{array}$ & 18 & 60 & 5 & 16 & 6 & 20 & 1 & 4 & & \\
\hline $\begin{array}{l}\text { 6.Konuyu somutlaştırmak için araç-gereçler } \\
\text { kullanıldı }\end{array}$ & 30 & 100 & & & & & & & & \\
\hline $\begin{array}{l}\text { 7.Sınıfin durumu değerlendirilerek hız } \\
\text { ayarlaması yapıldı. }\end{array}$ & 13 & 43 & 7 & 23 & 6 & 20 & 4 & 14 & & \\
\hline $\begin{array}{l}\text { 8.Konular akıcı ve mantıksal bir sira izleyerek } \\
\text { sunuldu. }\end{array}$ & 23 & 77 & 7 & 23 & & & & & & \\
\hline $\begin{array}{l}\text { 9. Konulara iliş̧kin konuşmalar açık ve } \\
\text { anlaşı1ırdı. }\end{array}$ & 19 & 63 & 8 & 27 & 3 & 10 & & & & \\
\hline 10.Tahtada yer alan yazılar okunaklıydı. & 18 & 60 & 5 & 16 & 7 & 24 & & & & \\
\hline $\begin{array}{l}\text { 11.Kullanılan araç-gereçler konuya uygun } \\
\text { seçilmişti. }\end{array}$ & 26 & 87 & 4 & 13 & & & & & & \\
\hline 12.Uygun seviyede gruplar oluşturuldu & 12 & 40 & 6 & 20 & 10 & 33 & 2 & 7 & & \\
\hline 13.Konuya ilişkin tartışmalar ilgi çekiciydi & 20 & 67 & 4 & 13 & 6 & 20 & & & & \\
\hline 14.Tartışma sırasında sınıf etkili yönetildi & 19 & 63 & 3 & 10 & 5 & 16 & 3 & 10 & & \\
\hline 15.İsbirliği düzenlemesi için uygun ortam vardı. & 26 & 87 & 3 & 10 & 1 & 4 & & & & \\
\hline 16.Oturma düzeni rahatlatıcı idi & 21 & 70 & 5 & 16 & 2 & 7 & 2 & 7 & & \\
\hline 17.Değerlendirmeler amacına uygun yapıldı. & 23 & 77 & 5 & 16 & 1 & 4 & 1 & 4 & & \\
\hline 18.Seçilen yöntem amaca uygundu. & 24 & 80 & 4 & 13 & 2 & 7 & & & & \\
\hline $\begin{array}{l}\text { 19.Başarı testi soruları konulara uygun } \\
\text { seçilmişti. }\end{array}$ & 26 & 87 & 4 & 13 & & & & & & \\
\hline $\begin{array}{l}\text { 20.Ders boyunca amaçların gerçekleşmesine } \\
\text { odaklanılmıştı. }\end{array}$ & 28 & 93 & 2 & 7 & & & & & & \\
\hline 21.İçerik zamana uygun olarak belirlenmişti. & 22 & 73 & 5 & 16 & 2 & 7 & 1 & 4 & & \\
\hline $\begin{array}{l}\text { 22.Sözel ve sözel olmayan pekiştireçler, uygun } \\
\text { şekilde kullanıldı. }\end{array}$ & 18 & 60 & 7 & 23 & 5 & 16 & & & & \\
\hline 23.Sınıf atmosferi oldukça demokratikti. & 23 & 77 & 7 & 23 & 1 & 4 & & & & \\
\hline $\begin{array}{l}\text { 24.Jest ve mimikler, dikkati derse toplamak } \\
\text { için uygun şekilde kullanıldı. }\end{array}$ & 20 & 67 & 6 & 20 & 3 & 10 & 1 & 4 & & \\
\hline 25.Yapılan etkinlikler iyice gözlemlendi. & 19 & 63 & 3 & 10 & 4 & 13 & 2 & 7 & 2 & 7 \\
\hline 26.Derste öğrencilerin fikirlerine de yer verildi. & 23 & 77 & 6 & 20 & 1 & 4 & & & & \\
\hline 27.Seçilen yöntem etkili şekilde kullanıldı. & 19 & 63 & 4 & 13 & 3 & 10 & 2 & 7 & 2 & 7 \\
\hline 28.Derse tam zamanında son verildi. & 17 & 57 & 7 & 23 & 6 & 20 & & & & \\
\hline 29.Derse iliskkin dönütler uygun verildi & 18 & 60 & 8 & 27 & 4 & 13 & & & & \\
\hline 30.Derse ilişskin dönütler zamanında verildi. & 19 & 63 & 7 & 23 & 4 & 13 & & & & \\
\hline
\end{tabular}

Tablo 6 incelendiğinde öğretim ilke ve yöntemleri dersinin planlama ve plan çeşitleri konusunun öğretimine ilişkin olarak deney grubunda yer alan adayların tamamı (\%100) dersin somut hale gelmesi için araç ve gereçlerin kullanıldığını, tamamına yakını (\%93) konulara ilişkin hedefler ve kazanımların açıkça belirtildiğini, ders boyunca amaçların gerçekleştirilmesine odaklanıldığını(\%93), araç ve gereçlerin konuya uygun olduğunu $(\% 87)$, işbirliği düzenlemesi için sınıf içinde uygun ortamın olduğunu(\%87) ve başarı testi sorularının konulara uygun olarak seçildiği (\%87) görüşlerine 
tamamen katıldıklarını belirtmişlerdir. Örnekleme dahil olan deney grubu adaylarının diğer maddelere verdikleri cevaplar dikkate alındığında ise büyük oranda her maddede yer alan görüşlere tamamen katıldıkları belirlenmiştir. Bu durumun öğretim ilke ve yöntemleri dersinin ilgili konularının Dick ve Carey öğretim tasarımına uygun bir düzenleme ile işlenmesinin olumlu bir sonucu olduğu söylenebilir.Derste yer alan diğer konuların da bu öğretim tasarımı modeline uygun bir düzende işlenmesinin, öğrencilerin sorun yaşayabilecekleri konuları daha etkili olarak öğrenmelerinde fayda sağlayacağı söylenebilir.

Tablo 7: Kontrol Grubu Öğretimi Değerlendirme Dağglımı

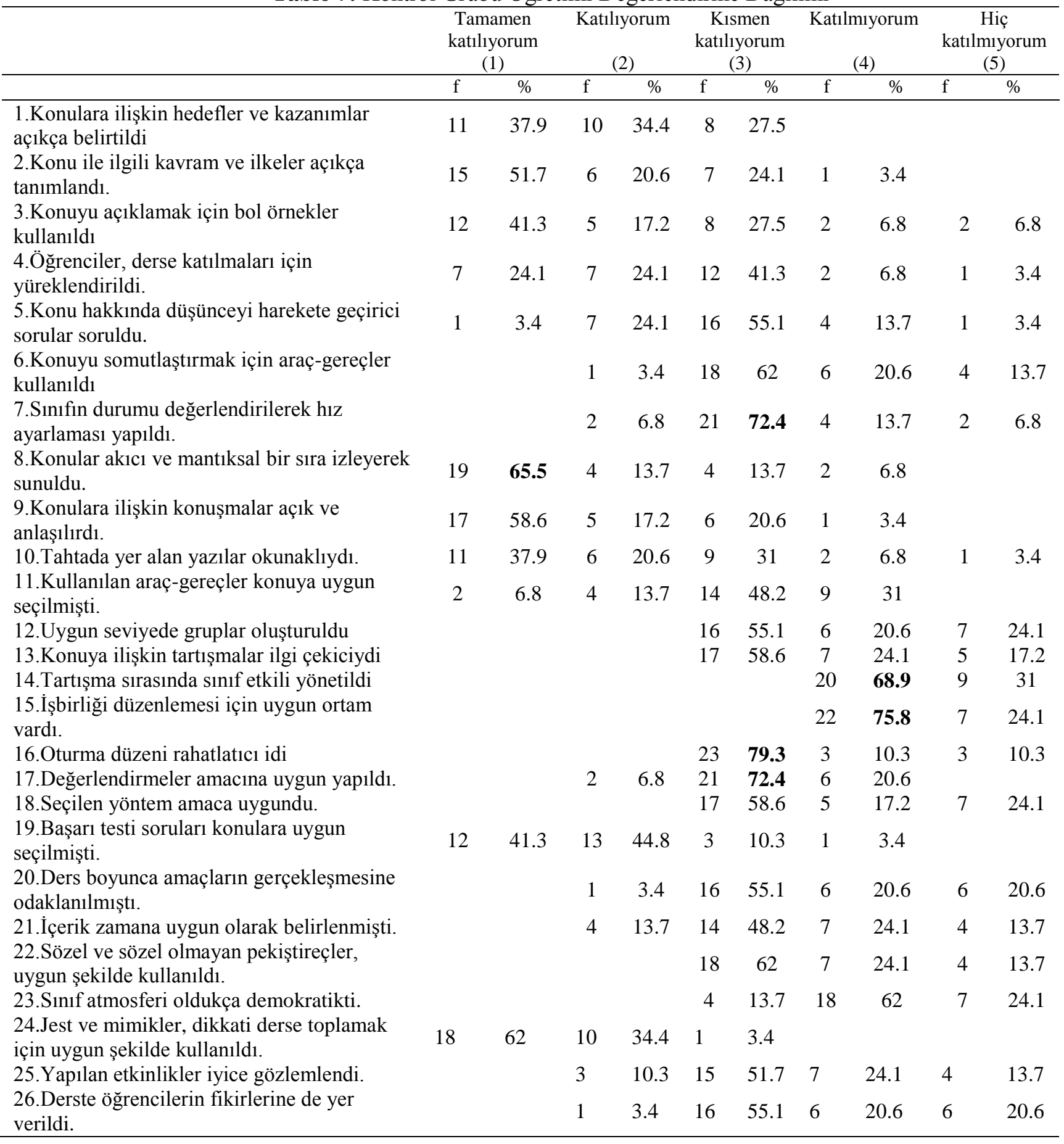




\begin{tabular}{lllllllllll}
\hline 27.Seçilen yöntem etkili şekilde kullanıld1. & & & 6 & 20.6 & 15 & 51.7 & 6 & 20.6 & 2 & 6.8 \\
28.Derse tam zamanında son verildi. & 11 & 37.9 & 9 & 31 & 7 & 24.1 & 2 & 6.8 & & \\
29.Derse ilişkin dönütler uygun verildi & 1 & 3.4 & 3 & 10.3 & 13 & 44.8 & 7 & 24.1 & 5 & 17.2 \\
30.Derse ilişkin dönütler zamanında verildi. & 5 & 17.2 & 4 & 13.7 & 15 & 51.7 & 4 & 13.7 & 1 & 3.4 \\
\hline
\end{tabular}

Tablo 7 incelendiğinde öğretim ilke ve yöntemleri dersinin planlama ve plan çeşitleri konusunun öğretimine ilişkin olarak kontrol grubunda yer alan adayların sırasıyla; sınıf içi oturma düzeninin rahatlatıcı olduğuna kısmen katıldıklarını(\%79.3), sınıfta işbirliği düzenlemesi için uygun ortam olduğu görüşüne katılmadıklarını(\%75.8), sınıfın durumunun değerlendirilerek hız ayarlaması yapıldığı görüşüne kısmen katıldıklarını (\%72.4) tartışma sırasında sorunlara karşı önlemlerin zamanında alındığı görüşüne katılmadıklarını(\%68.9) ve konuların akıcı ve mantıksal bir sıra izleyerek sunulduğu görüşüne tamamen katıldıklarını(\%65.5) belirtmişlerdir. Örnekleme dahil olan kontrol grubu adayların diğer maddelere verdikleri cevaplar incelendiğinde ise geniş bir yelpazede dağılım göstermekle birlikte, her maddede yer alan görüşlere kısmen katıldıkları ve katılmadıkları yönünde ağırlık kazandığı görülmektedir. Bu durumun öğretim ilke ve yöntemleri dersinin ilgili konularının geleneksel bir öğretim uygulaması ile işlenmesinin bir sonucu olduğu söylenebilir. Derste yer alan diğer konuların da bu şekilde bir düzende işlenmesinin, öğrencilerin derse ilişkin sorun yaşayabilecekleri konuların sayısında artışa sebebiyet verebileceği beklenebilir.

\section{Sonuç ve Öneriler}

Öğretmen adayları öğretim ilke ve yöntemleri dersinde en çok sırası ile; hedef ve davranış ayrımı, yazımı ve aşamalı olarak sıraya koyma, plan çeşitlerini öğeleri bakımından birbirinden ayırma, hazırlanmış olan günlük ders planı örneklerini değerlendirme, plan yapmanın önemini açıklama ve farklı planların tanımlarını yapma becerilerinde sorun yaşamaktadırlar. Ders planı hazırlama becerisi, kazanıma uygun yöntem, materyal ve etkinlik seçme ya da geliştirme, gerçek yaşam örnekleri kurgulama ve işlenişi planlama gibi işlemleri; ders planı uygulama becerisi ise, planlanan kuram ya da modelin gerçek ya da gerçeğe yakın durumlarda kullanılması işlemlerini kapsamaktadır. Aşiroğlu ve Akran(2018) tarafından yapılan araştırma sonuçlarına göre de benzer biçimde öğretmen adaylarının öğretim ilke ve yöntemlerine yönelik ders planı hazırlamadaki performansları orta seviyededir. Ders planlamada düşük performans gösteren adayların ise öğrenme yaklaşımlarını örneklendiremedikleri ve öğretim ilke ve yöntemlerine ilişkin kavramları bilgi düzeyinde edindikleri görülmüştür. Kablan (2012) tarafından yapılan araştırma sonuçlarına göre de; öğretmen adaylarının ders planı hazırlama becerisinin, ders planı uygulama becerisinin önemli bir yordayıcısı olduğu ve bilişsel öğrenme ve somut yaşantı düzeyi arasında da anlamlı bir ilişkiye etki ettiği tespit edilmiştir. Ceyhan ve Güven (2014) tarafından yapılan araştırma sonuçlarına göre de; öğretmen adaylarının belirledikleri plan içeriğine göre ders planı hazırlamaları öğretimin niteliğini artırma yanında öğrencilerin ders başarılarına da olumlu katkı sağladığını düşündüklerini ortaya çıkarmıştır. Bu nedenle öğretmen yetiştirme programlarında öğretmen adaylarının ders planı hazırlığı konusunda kuramsal ve uygulamalı içerikleri önemsemesinin sağlanması ve ders planı hazırlamanınöğretim mevzuatı gerekliliğinin dışında öğretim sürecini daha etkili hale getirmek açısından öneminin algılanması gerekmektedir

Öğretmen adaylarının baskın zeka alanları incelendiğinde kontrol grubunun sözel dil alanı baskı iken deney grubundaki adayların sözel, görsel, kinestetik ve sosyal zeka alanlarında daha baskın oldukları görülmüştür. Korkmaz ve Arkadaşları (2009) tarafından yapılan araştırma sonuçlarına göre de; farklı bölümlerdeki öğretmen adaylarının baskın zeka tipleri çeşitlilik göstermektedir. Örneğin Fen bilgisi öğretmenliği bölümündeki öğretmen adaylarının mantıksal-matematiksel, diğer bölümlerdeki öğretmen adaylarının ise sosyal zeka algıları daha yüksektir. Diğer taraftan, sınıf öğretmenliği ve fen bilgisi öğretmenliği bölümlerindeki öğretmen adaylarında müziksel-ritmik, diğer bölümlerdeki ögretmen adaylarında ise görsel-uzamsal zeka algıları daha düşük bulunmuştur. Ayrıca Aksu ve Arkadaşları ( 2012 ) ise yaptıkları araştırma da okulöncesi öğretmen adaylarının en fazla mantıksalmatematiksel zekâyı en az ise kişiler arası-sosyal zekâyı kullanmayı tercih ettiklerini 
belirlenmişlerdir. Öztürk ve Arkadaşlarının(2017) ortaya koydukları sonuçlara göre de; öğretmen adaylarının özellikle doğacı, içsel ve kişiler arası zekâ bölümlerinde genel puan ortalamaları diğer zekâ bölümlerine göre daha yüksektir. Bu bulgulara göre öğretmen adayları üzerinde yapılan farklı zamanlardaki araştırmalar sayesinde de farklı tür zeka alanlarının tespit edildiği ve baskın olmayan zeka alanlarının derse ait öğrenen merkezli yöntem ve tekniklerin uygulanması sayesinde de geliştirilebileceği söylenebilir.

Öğretim ilke ve yöntemleri dersine ait eğitim -öğretim etkinliklerinin planlanması ünitesi dahilindeki planlama ve plan çeşitleri konularının öğretiminin, Dick ve Carey öğretim tasarımı modeline uygun bir düzenleme ile gerçekleştirilmesinden önce öğretim elemanları, dersin giriş bölümünde konuya ilişkin kavram ilke ve genellemelerin öğretimi için anlatım ve soru-cevap yöntemlerini içeren sunuş stratejisini ve U biçiminde oturma düzenini, dersin ilerleyen bölümlerinde ise, işbirlikçi stratejilere dayalı, tartışma ve soru-cevap yöntemlerinin çember düzen oturma biçiminde kullanılmasının uygun olacağını belirtmişlerdir. Ayrıca derse ilişkin materyallerin ve araç-gereçlerinde zamanında devreye sokularak, hem dersi somut hale getirme de hem de öğrencilerin uygulama saatlerinde konuya ilişkin olarak verimli çalışmalar yapmalarında etkili olacağını açıklamışlardır. $\mathrm{Bu}$ bulguları destekler nitelikte Cheolil ve arkadaşları (2011) yaptıkları araştırma sonucunda, ilkokul öğretmenlerinin özellikle planlama, materyal, uygulama ve değerlendirme becerilerini geliştirmeleri bakımından Dick ve Carey öğretim tasarımı modelini kullanmalarının oldukça faydalı olduğunu belirtmişlerdir. Kutluca ve Arkadaşları(2007) tarafından yapılan araştırma sonuçlarına göre de; öğretmen adayları öğretim ilke ve yöntemleri dersi içinde yaptıkları uygulamaya dayalı grupa çalışması etkinliklerinin mesleki becerileri edinmede daha kalıcı bir öğrenmeye yol açtığını ve bu uygulamaların gelecekteki mesleki yaşamlarında da onlara faydalı olacağını düşündüklerini ortaya koymuştur. Ayrıca Topbaş ve Toy (2005) tarafından yapılan araştırma sonuçlarına göre de; öğretmen adaylarının "Öğretimde Planlama ve Değerlendirme" dersinin öğrenilmesinde ve hedeflerin kazanılmasında uygulama etkinliklerinin daha etkili olduğunu düşündükleri tespit edilmiştir. Bununla birlikte Atik (2012) ve Christofferson ve Sullivan (2015) tarafından yapılan farklı araştırma sonuçları ise bu türdeki meslek bilgisi derslerinin öğretmen adaylarının planlama ve teorik bilgilerini uygulamaya aktarma yeterliliklerini kazandırmada oldukça yetersiz kaldığını ifade etmektedirler.

Dick ve Carey öğretim tasarımı modeline göre işlenen derse katılan deney grubu adayların, bu derse katılmamış olan kontrol grubu adaylarına göre akademik başarı puanları daha yüksek bulunmuştur. Bu bulgunun Dick ve Carey öğretim tasarımı modeline göre planlanan öğretim ilke ve yöntemleri dersinin adayların sorun yaşadıkları konuları öğrenmelerinde ve akademik başarılarını yükseltmede etkili olduğu söylenebilir. Ayrıca işleniş sırasında deney grubunun sahip olduğu farklı zeka alanlarına uygun strateji ve yöntemlerin kullanılmasının da kontrol grubuna göre başarıyı arttırdığı düşünülebilir. Nitekim Natsir (2017) tarafından yapılan araştırma sonucuna göre; öğretmenlerin Dick ve Carey öğretim tasarımına uygun düzenlenmiş öğrenme ve öğretme etkinliklerinin geliştirme uygulama ve değerlendirme süreçleri boyunca ortaöğretim öğrencilerinin derse ait amaçları, ders kitabı ve derse ait materyalleri öğrenme düzeyleri bakımından olumlu yönde bir gelişmeye yol açtığı tespit edilmiştir. Dikmen (2019) tarafından yapılan araştırmada da, Dick ve Carey öğretim tasarımına uygun düzenlenmiş fen öğretiminin altıncı sınıf düzeyindeki öğrencilerin motivasyonları, öğrenme davranışları ve akademik başarıları arasında anlamlı bir ilişkiye yol açtığı belirlenmiştir. Göksu ve arkadaşları (2014) tarafindan yapılan araştırma sonucuna göre de; modelin akademik başarıyı diğer modellere göre artırdığı uygulanmasının tercih edildiği belirtilmiştir.

Öğretim ilke ve yöntemleri dersinin planlama ve plan çeşitleri konusunun öğretimine ilişkin olarak deney grubunda yer alan adayların kontrol grubunda yer alan adaylara göre büyük oranda dersin somut hale gelmesi için araç ve gereçlerin kullanıldığını, konulara ilişkin hedefler ve kazanımların açıkça belirtildiğini, ders boyunca amaçların gerçekleştirilmesine odaklanıldığını, araç ve gereçlerin konuya uygun olduğunu, işbirliği düzenlemesi için sınıf içinde uygun ortamın olduğunu ve başarı testi sorularının konulara uygun olarak seçildiği görüşlerine tamamen katıldıklarını 
belirtmişlerdir. $\mathrm{Bu}$ durumun öğretim ilke ve yöntemleri dersinin ilgili konularının Dick ve Carey öğretim tasarımına uygun bir düzenleme ile işlenmesinin olumlu bir sonucu olduğu söylenebilir. Nitekim Akbulut (2007) tarafından farklı öğretim tasarımlarının karşılaştırmalı olarak incelendiği araştırma sonucunda da, bu öğretim tasarımının derse ait öğretim materyalleri ile öğrencilerin materyalleri de öğrenmeleri arasında bir ilişki ortaya koyduğu açıklanmış ve özellikle deneyimsiz aday öğretmenler için daha kesinleşmiş ve kuralcı öğretim adımları sunduğu da belirtilmiştir. Friedman (2018) tarafindan yapılan araştırmada da, bu modelin görselleştirme eğitim programlarının geliştirilmesi amacıyla kullanımının öğrenenlerin etkili pedagojik becerileri kullanmalarına yönelik ileri düzeyde davranışlar geliştirmesine sebep olduğu belirtilmiştir. Ayrıca Uyar (2016) tarafindan yapılan araştırma sonuçları; ögretim ilke ve yöntemleri dersinde bilgiyi sunma ve anlamlandırma, bakımından otantik öğrenme yaşantılarının sunulduğu ve öğrenci merkezli yaklaşımı temel alan bir öğrenme öğrenme-öğretme sürecine gereksinimi ortaya çıkarmıştır. Bu bulgular ışığında dersin diğer konularının da bu öğretim tasarımı modeline uygun bir düzende işlenmesinin, öğrencilerin sorun yaşayabilecekleri konuları daha etkili olarak öğrenmelerinde fayda sağlayacağı söylenebilir.

Deney ve kontrol grubunda yer alan öğretmen adaylarının hem ders başarıları hem de ders öğretimlerini değerlendirmeye ilişkin görüşleri arasındaki farklılıklar olduğu belirlenmiştir. Kontrol grubunda akademik başarının düşüşü ile ders öğretimine ilişkin olumsuz görüşler arasında bir paralellik olduğu, tersine akademik başarı düzeyi yüksek olan deney grubunun ders öğretimine ilişkin görüsslerinin ise daha olumlu olduğu söylenebilir. Dick ve Carey öğretim tasarımı modeline uygun olarak düzenlenen etkinliklerin öğretmen adaylarının sorunlu buldukları konuları daha iyi öğrenmelerinde olumlu bir katkı yarattığı, akademik başarılarını olumlu yönde arttırdığı ve geleneksel öğretime göre, ders öğretiminin etkililiğinin öğretmen adayları üzerinde de olumlu izlenimler bıraktığı ortaya çıkmıştır. Benzer biçimde Uyar (2016) tarafından yapılan araştırma sonuçlarına göre de; ögretmen adaylarının öğretim ilke ve yöntemleri dersinin anlama ve beceri düzeyinde amaçlarının olmasını ve içerik yoğunluğunun da azaltılması gerektiğini belirtmişlerdir. Esmer (2017) tarafından Dick, Carey ve Carey modelinin, Sınıf Yönetimi dersi "Sınıf Kuralları Geliştirme ve Uygulama" konusuyla ilişkili olarak öğrenci başarısına etkisinin incelendiği araştırma sonuçları da modelin akademik başarıyı olumlu yönde artırdığı sonuçlarını ortaya koymuştur.

Sonuç olarak, sınırlı bir üniteye dayalı konuların öğretimi için seçilmiş olan bu tasarım uygulaması sonuçlarının sınırlı bir çerçevede bu düzeyde anlamlı ve olumlu yönde bir gelişmeye yol

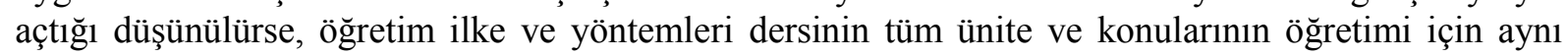
modelin uygulanması durumunda öğretmen adaylarının ders başarıları üzerinde oldukça olumlu yönde anlamlı bir farklılığa ve gelişime yol açacağı da söylenebilir. Öğretim elemanlarının da ders konularına uygun materyaller geliştirmeleri yanında öğrencilerin işbirlikçi çalışma düzenleri doğrultusunda hareket etmeleri için rehber olmaları gerektiği düşünülebilir. Diğer öğretmenlik meslek bilgisi dersleri içinde, öğretmen adaylarının öğrenmede güçlük çektikleri konuların öğretiminde Dick ve Carey öğretim tasarımı aşamalarının kullanılması önerilebilir. Yükse öğretim programında yer alan diğer derslere ait konuların öğretimlerinde hangi tip öğretim tasarımlarının öğretmen adayları üzerinde daha etkili olabileceği araştırılarak ve öneriler getirilmelidir.

\section{KAYNAKÇA}

Akbulut Y. (2007). Implications of TwoWell-KnownModels for Instructional Designers In Distance Education: Dick-Carey Versus Morrison-Ross-Kemp. Turkish Online Journal Of Distance Education-Tojde, 8 (2) 1-7.

Aksu Ö. , Aktaş M, Gökmen A, Ekici G, Ogelman H G ( 2012) Okulöncesi Öğretmen Adaylarının Çoklu Zekâ Alanlarının Farklı Değişkenlere Göre Değerlendirmesi, Bayburt Üniversitesi Eğitim Fakültesi Dergisi (7) 2. 20-38 
Aşiroğlu, S., Koç Akran, S. (2018). Öğretmen Adaylarının Ders Planlarının ve Öğretim Uygulamalarının İncelenmesi. E-Kafkas Eğitim Araştırmaları Dergisi, 5(3), 1-13.

Atik Kara, D. (2012). Öğretmenlik Meslek Bilgisi Derslerinin Öğretmen Adaylarına Öğrenme ve Öğretme Sürecine İlişkin Yeterlilikleri Kazandırması Yönünden Değerlendirilmesi. Yayımlanmamış Doktora Tezi, Anadolu Üniversitesi Eğitim Bilimleri Enstitüsü, Eskişehir.

Bay, E.; Karakaya, S. (2009). Öğretmen Eğitiminde Yapılandırmacı Yaklaşıma Dayalı Uygulamaların Etkililiğinin değerlendirilmesi. Elektronik Sosyal Bilimler Dergisi, 8(28), 40-55.

Braden, R. A. (1996). The Case for Linear Instructional Design and Development: A Commentary on Models, Challenges, andMyths. EducationalTechnology, 36(2), 5-23.

Briggs, L. J.,Gustafson, K. L. \&Tellman, M. H., Eds. (1991). Instructional Design: Principlesand Applications, Second Edition. Educational Technology Publications,

Büyüköztürk, Ş. (2012). Örnekleme yöntemleri. 20.05.2018 tarihinde http://w3.balikesir.edu.tr/ msackes/wp/wp-<content/uploads/2012/03/BAY-FinalKonulari.pdf $>$ erişim sağlandı.

Ceyhan, G. D. Güven D.(2014) Fen Bilgisi Öğretmen Adaylarının Ders Planı Hazırlama Ve Uygulamaya İlişskin Görüssleri 11. Ulusal Fen Bilimleri ve Matematik Eğitimi Kongresi (UFBMEK), Çukurova Universitesi, Eylül Adana

Christofferson, M.\& Sullivan, A. L. (2015). Pre-service teachers' classroom management training: a survey of selfreported training experiences, content coverage and preparedness. Psychology in the Schools, 52(3), 248-264. DOİ: 10.1002/pits.21819

Dick, W. (1996). The Dickand Carey model: Will it survive the decade? Educational technology research and development, 44(3), 55-63.

Dick, W.,\&Carey, L. (1990). The systematic design of instruction ( 3rd ed.). Glenview, IL: Scott Foresman.

Dick, W.,\&Carey, L. (2004). The Systematic The Systematic Design of Instruction Design of Instruction. (6th Edition).,LouAllyn\& Bacon.

Dick, W.,Carey, L., \&Carey, J. O. (2001). Thesystematicdesign of instruction (5th ed.). NY: AddisonWesleyEducational Publishers. USA.

Dick, W.,Carey, L., \&Carey, J. O. (2009). The systemati cdesign of instruction. Upper Saddle River, NJ: Merrill.

Dicks, D.,Garzotto, F., Hedberg, J. \&Zeng, Y. (2005). Imagining a Science of Instructional Design. In P. Kommers\& G. Richards (Eds.), Proceedings of ED-MEDIA 2005--World Conference on Educational Multimedia, Hypermedia\&Telecommunications (pp. 960-965).

Dikmen, C. H. (2019). The effect of web-based instruction designed by dick and carey model on academic achievement, attitude and motivation of students' in science education, Journal of Learning and Teaching in Digital Age, 4, (1), 34-40

E Cliffs, N.J. Edmonds, G. S.,Branch, R. C., \&Mukherjee, P. (1994). A Conceptual Framework for Comparing Instructional Design Models, Educational Researchand Technology, 42(2), 5572.

Esmer E. (2018). Öğretim Tasarımında Bir Model: Dick, Carey ve Carey. Trakya Üniversitesi Eğitim Fakültesi Dergisi, 8, (2), 274-284. 
Esmer, E. (2017).Dick, carey ve carey modeli’ne ilişkin bir değerlendirme. Uşak Üniversitesi Eğitim Araştırmaları Dergisi, 3(3), 52-75.

Fotiyeva, I. S. (2013). Constructing An Instructional Design Frame Work That Incorporates RePurposing Popular Mediato Enhance Mathematics and Science Instruction (Doctoral dissertation, Virginia Tech).

Friedman, A.,\& Schneider, E. (2018). Developing a Visualization Education Curriculum in the Age of Big Data Using the Dick and Carey Model. Visual Communication Quarterly, 25(4), 250256.

Gagne, R.M. (1997). Learning and instructional design. PerformanceImprovementQuarterly10(1), 819.

Gagne, R.M.,Briggs, L.J., \&Wager, W.W. (1992). Principles of instructionaldesign ( 4th ed.). Orland FL: Harcourt, BraceCollage Publishers,4-16pp.

Göksu, İ., Özcan, K. V., Çakır, R., \& Göktaş, Y. (2014). Türkiye'de öğretim tasarımı modelleriyle ilgili yapılmış çalışmalar. İlköğretim Online, 13(2), 694-709.

Gustafson, Kent L., (1993) Instructional design foundamentals; Could On TheHorizon. Educational Technology, 33(2), 27-32.

Gülşen, C. (2015). Çoklu zekâ alanları değerlendirme ölçeği geliştirilmesi çalışması. International Journal of Human Sciences, 12(2), 1918-1930.

Güney, K.; Semerci, Ç. (2009). Mikro-Yansıtıcı Öğretim Yönteminin Öğretmen Adaylarının Yansıtıcı Düşünmesine Etkisi. Doğu Anadolu Bölgesi Araştırmaları Dergisi. 8(1), 77-83.

Han, M. K. (2009). A study on teaches' and students' perception of theuse of moving Picture materials in elementary science classes. Unpublished master thesis. Korea National University of Education, Chungchungdo.

İşman,A., Çağlar,M.\&Diğg. 2005 “A New Model forThe World of İnstructional Design: A New Model" The TurkishJournal of Educational Technology, Jully,4 (3),33

Kablan, Z.(2012) "Öğretmen Adaylarının Ders Planı Hazırlama ve Uygulama Becerilerine Bilişsel Öğrenme ve Somut Yaşantı Düzeylerinin Etkisi” Eğitim ve Bilim,(37)163,239-253

Karaca, F.,Yildirim, S., \& Kiraz, E. (2008). Elementary School Teachers' Instructional Design Process: An Insight into Teachers' Daily Practices. In Societyfor Information Technology\&Teacher Education International Conference (pp. 3364-3371), March, Association for the Advancement of Computing in Education (AACE).

Khadimally, S. (2019) DickandCareyInstructional Design Model, University of Phoenix, 01.04.2018 tarihinde <https://www.academia edu/10716292/DickandCareyInstructional Design_Model> adresinden erişildi.

Kılıç, A.; Acat, M. B. (2007). Öğretmen Adaylarının Algılarına Göre Öğretmen Yetiştirme Programlarındaki Derslerin Gereklilik ve İșe Vurukluk Düzeyi. Sosyal Bilimler Dergisi, 17, 21-37.

Kirschner, P.,Carr, C., \& Van Merrienboer, J. J. G. (2002). How expert designers design. Performance Improvement Quarterly, 15(4), 86-104.

Korkmaz Ö., R. Yeşil, Aydın,D. (2009) Öğretmen Adaylarının Çoklu Zeka Algıları, Ahmet Keleşoğlu Ĕ̈itim Fakültesi Dergisi, AydınSelçuk Üniversitesi s. 27, 221 -239, 
Kutluca, T.Birgin O. Çatlığlu, H.(2007) Öğretimde Planlama ve Değerlendirme Dersi Uygulama Etkinliklerinin Öğretmen Adaylarına Sağladığı Faydalar, Uludă̆ Üniversitesi Ĕgitim Fakültesi Dergisi XX (1), 89-110

Lebow, D. (1993). Constructivist values for instructional systems design: Five principles toward a newmindset. Educational technology research and development, 41(3), 4-16.

Lim, C.,Choi, S., Hong, M., \& Han, S..A Developmental Study of an Instructional Systems Design Model for Elementary School Teachers. Selected Researchand Development Papers and Selected Papers on the Practice of Educational Communications and Technology 34thannual, Jacksonville(pp154).

Mager, R. F. (1997). Preparing instructional objectives: A critical tool in the development of effective instruction. Atlanta, GA: CEP Press, 193, ISBN: 1-879-618-036

Martin, B. L.,\&Clemente, R. (1990). Instructional systems design and public schools. Educational Technology Research and Development, 38(2), 61-75.

MatthewF. Rose (2000); The Systematic Design of Instruction, Chapter 4 Summary. Conducting a Subordinate Skills Analysis, 20-22

McGriff, S. (2000) Instructional systems design models, 20.05.2018 tarihinde $<\mathrm{http} / / / w w w . p e r s o n a l . p s u . e d u / f a c u l t y / s / j \quad$ sjm256/portfolio/kbase/IDD/ISDModels.html> adresinden erişildi.

Moallem, M. (1998). An expert teacher's thinking and teaching and instructional design models and principles: An ethnographic study. Educational Technology Research and Development, 46(2), 37-64.

Natsir, M. (2017). Pengembanganpembelajara $\mathrm{n}$ fikıh kelas $\mathrm{x}$ madrasahalıyahdalam model dick\&carey, Jurnal Pendidikan Agama Islam (Journal Of IslamicEducationStudies), 2017;5(1):44-67.

Okubo, N., Nara, K., Takemura, S., \&Ueda, Y. (2016, April). Applying an Instructional Design Processto Development of an Independent Verification and Validation Training Program. In 2016 IEEE 29th International Conference on Software EngineeringEducationand Training (CSEET) ,237-240, IEEE.

Öztürk Adil A., Özsoy N. , Vural Ruken A. , Baysan S.(2017) Öğretmen Adaylarının Çoklu Zekâ Bölümlerine İliş̧kin Algılarının Karşılaştırmalı Perspektiften İncelenmesi Adnan Menderes Üniversitesi Sosyal Bilimler Enstitüsü Dergisi, (4) 3 . 18-32

Park, K. (2007). Instructionaldesign model andpractice: A survey of designpractice. Journal of EducationalTechnology, 23(4), 1-30.

Reiser, R. A. (1994). Examining the planning practices of teachers: Reflections on three years of research. Educational Technology, 34(3), 11-16.

Reiser, R. A.,\&Dempsey, J. V. (2002). Trends and issues in instructional design and technology. UpperSaddleRiver, NJ: Merrill/PrenticeHall,

Reiser, R. A.,\&Dempsey, J. V. (Eds.). (2012). Trends and issues in instructional design and technology. 342-367.Boston, MA: Pearson.

Swapnil. (2008). The Dick and Carey Systems Approach Model of Instructional Design. 23.03.2011 tarihinde.:http://insightlopedia.wordpress.com/2008/10/13/the-dick-and-carey-systemsapproach-model-of-instructional-design/ > adresinden erişildi. 
Topbaş, E., Toy, B.Y. (2005) Kalabalık Sınıflarda Öğrenci Merkezli Öğretim Uygulamaları: Öğretimde Planlama ve Değerlendirme Dersi Örneği,14.Ulusal Ĕ̆itim Bilimleri Kongresi. Pamukkale Üniversitesi

U.Ü.(2005) “Öğretim ilke ve yöntemleri Ders Tanımı”,Öğrenci El Kitabı, Uludağ Üniversitesi Basımevi, Bursa.

William Winn, 1993.A Conceptual Basis for Educational Applications of Virtual Reality, Human Interface Technology Laboratory, Washington Technology Center, University of Washington, Technical Publiciation,93-9, August

Yeşilpınar, Uyar, M. (2016). Öğretim İlke Ve Yöntemleri Dersine Yönelik Okul Temelli Öğretim Programı Geliştirmeye İlişkin Bir İhtiyaç Analizi Çalışması. Pegem Eğitim ve Öğretim Dergisi, 6(1), 73-96, http://dx.doi.org/10.14527/pegegog.2016.005.

Young, A. C.,Reiser, R. A., \&Dick, W. (1998). Do superior teachers employ systematic in structional planning procedures? A descriptivestudy. Educational Technology Researchand Development, 46(2), 65-78.

YÖK. (2007). Öğretmen Yetiştirme ve Eğitim Fakülteleri (1982-2007) : 22.07 .2017 tarihinde <https://www.yok.gov.tr/Documents/Yayinlar/Yayinlarimiz/ogretmen-yetistirme-ve-egitimfakulteleri.pdf $>$ erişim sağlandı. 